AP10

Depositional Nature of the Triassic Jilh Lower
Carbonates: A Proven Hydrocarbon Play in West
Kuwait Area

\author{
R.T. Arasu* (Kuwait Oil Company), B.V. Rama Rao (Kuwait Oil Company), \\ S. Das (Kuwait Oil Company) \& R.I.A. Abu-Taleb (Kuwait Oil Company)
}

\title{
SUMMARY
}

Jilh carbonate succession represents Middle to Late Triassic stratigraphy in Kuwait. It is deposited in shallow marine inner ramp and restricted settings. Three major lithofacies units are recognized based on well data: Jilh Lower Carbonates which is overlying the Early Triassic Sudair Formation, Jilh Dolomite in the middle and Jilh Upper Carbonates. A thin salt layer, near absent at places, separates the bottom unit from the upper ones. The entire sequence from top to bottom is characterized by numerous thin anhydrite layers, exhibiting prevalence of arid climate. Whereas Jilh Dolomite and Upper Carbonate sequences are regionally consistent with near uniform thickness, the bottom unit occurs with highly varying thickness ranging from 300' to 800'. Increase in thickness is seen mainly in the western parts of Kuwait where it is also referred to as 'Kra AlMaru' Unit. It comprises mainly dolowackestone and dolomudstones. Good amount oil and gas flowed from these reservoirs during initial testing in a couple of wells. Therefore, the depositional pattern may be interesting from the oil exploration point of view. 


\section{Depositional nature of the Triassic Jilh Lower Carbonates, a proven hydrocarbon play, in West Kuwait Area}

Raju T Arasu, Busi Venkata Rama Rao, Surajit Das and Reyad Ibrahim Ali Abu-Taleb, Kuwait Oil Company

Introduction

Jilh carbonate succession represents Middle to Late Triassic stratigraphy in Kuwait. It is deposited in shallow marine inner ramp and restricted settings. Three major lithofacies units are recognized based on well data: Jilh Lower Carbonates which is overlying the Early Triassic Sudair Formation, Jilh Dolomite in the middle and Jilh Upper Carbonates. A thin salt layer, near absent at places, separates the bottom unit from the upper ones. The entire sequence from top to bottom is characterized by numerous thin anhydrite layers, exhibiting prevalence of arid climate. Whereas Jilh Dolomite and Upper Carbonate sequences are regionally consistent with near uniform thickness, the bottom unit occurs with highly varying thickness ranging from 300' to $800^{\prime}$. Increase in thickness is seen mainly in the western parts of Kuwait where it is also referred to as 'Kra AlMaru' Unit. It comprises mainly dolowackestone and dolomudstones. Good amount oil and gas flowed from these reservoirs during initial testing in a couple of wells. Therefore, the depositional pattern may be interesting from the oil exploration point of view.

Methodology

The study area comprises Kra-AlMaru, Kahlulah, Minagish and Umm Gudair fields of West Kuwait which have been producing from Jurassic and Cretaceous reservoirs. The area is about $2200 \mathrm{~km}^{2}$ and is covered by adjacent high density 3D seismic surveys of two different vintages. Respective PSTM volumes were used to map the structures at Triassic Levels. The top and base of the Jilh Lower Carbonate sequence comprising the pay horizons are mapped by recognizing the internal and external seismic reflection patterns in both of the data volumes.

Results

The isopach map of Jilh Lower Carbonate sequence shows 500' to 700' contours form a prominent closure around Kra AlMaru structure in the northwest of the study area. The feature is oriented east west and has an areal extent of $240 \mathrm{~km}^{2}$. Apparently the depocenter was created by a cross fault system. In the rest of the study area less than 400 ' of the sequence is mapped. On the crestal parts of Minagish and Umm Gudair structures the sequence is thin, of the order of 300'. Further, thin isopach is also mapped on the western flank of Umm Gudair structure, where a carbonate mound is developed within the underlying Sudair Formation. Frequency attributes show absorption of higher frequencies in this area indicating likely presence of lighter hydrocarbons in the pinchout zone.

\section{Conclusion}

The deposition of Jilh Lower Carbonate sequence is possibly influenced by availability of accommodation space rather than sea level rise in the area. Some of the sub-units developed in paleo-lows might have pinched out against Minagish and Umm Gudair structures in the south. Thus, the isopach map of the lower Jilh sequence probably depicts the Early Middle Triassic paleo-topography. Apart from structural closures, pinchout zone on the western flank of Umm Gudair structure is also a promising subplay for hydrocarbon exploration. 